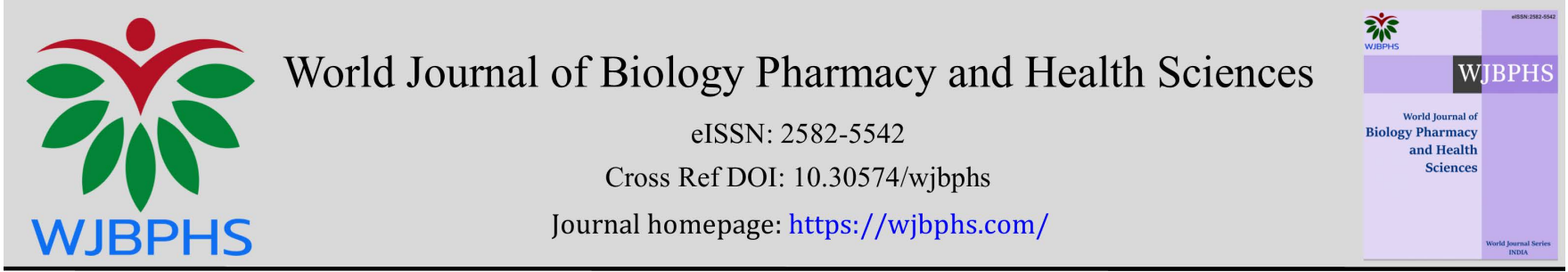

(RESEARCH ARTiCLE)

\title{
Pharmacognostic screening and antiemetic evaluation of the ethanol extract of the leaves of Morinda lucida benth. (rubiaceae)
}

\author{
Osuala Felix $\mathrm{N}^{1,}{ }^{*}$, Innocent Janet Amarachi ${ }^{1}$ and Uchenna E Odoh ${ }^{2}$ \\ ${ }^{1}$ Department of Pharmacognosy, Madonna University Nigeria, Elele Campus, Rivers State, Nigeria. \\ 2 Department of Pharmacognosy and Environmental Medicine, University of Nigeria, Nsukka, Nigeria.
}

World Journal of Biology Pharmacy and Health Sciences, 2021, 07(03), 001-014

Publication history: Received on 05 July 2021; revised on 31 August 2021; accepted on 02 September 2021

Article DOI: https://doi.org/10.30574/wjbphs.2021.7.3.0083

\begin{abstract}
Emesis is a common side and adverse effect associated with many illnesses, even drugs. It is the act or process of vomiting. Causes vary from pregnancy, morning sickness, motion sickness, chemotherapy and so on. Emetics are drugs or substances that induce vomiting. Antiemetics are agents given to stop vomiting and to stop the nauseous feeling. Morinda lucida, Benth. family, Rubiacae. It is commonly known as brimstone tree. It is about $24 \mathrm{~m}$ long, the branches are fibrous in nature and does not break easily, the tree bark is brown to grey, the leaves are green with green fruits.

This project is focused on the pharmacognostic evaluation and antiemetic activities of the ethanol extract of the leaves of Morinda lucida.

The plants were properly collected and identified by a taxonomist, then, air dried at room temperature, blended using an electric miller. The ethanol leaf extract of the plant was obtained using cold maceration, filtered and concentrated using rotary evaporator. The extract was used for antiemetic evaluations, pharmacognostic and chromatographic (thin layer chromatography) evaluations. The LD50 was determined using Lorkes method. Pharmacognostic evaluation shows the presence of, lignin, cellulose, saponin, tannis, alkaloids flavonoids. The LD50 shows that there was no death recorded. The result of the research shows that the ethanol extract of Morinda lucida on 2 weeks old chickens exhibited antiemetic effect.
\end{abstract}

It can therefore be concluded that the ethanol extract of Morinda lucida possess antiemetic activity as claimed and the result of these findings can be of great importance to the development of new antiemetic drug.

Keywords: Pharmacognostic: Morinda lucida: Rubiaceae: Antiemetic: Secondary metabolite: Ethanol extract

\section{Introduction}

\subsection{Herbal medicine}

Herbal medicine is the use of herbs for therapeutic or medicinal usefulness and value to prevent, treat, relief various illnesses. Traditional medicine has been used worldwide for treatment of several disease. Most people who do not have access to orthodox medicine rely on traditional medicine. Traditional medicine sometimes are preferred to orthodox medicine due to the side effects accustomed with the orthodox drugs. Traditional medicine are easily affordable, it can be from your backyard, fence, gate, even in a neighbors garden. Traditional medicine ranges from plants drugs, animals

${ }^{*}$ Corresponding author: Osuala Felix N

Department of Pharmacognosy, Madonna University Nigeria, Elele Campus, Rivers State, Nigeria.

Copyright (C) 2021 Author(s) retain the copyright of this article. This article is published under the terms of the Creative Commons Attribution Liscense 4.0. 
parts drug,, insects and so many other materials and substances that traditional practitioner can lay his hands upon (Sofoworaet al.,1993) [1].

A drug herb is a plant valued for its medicinal, narcotic and savoury qualities. Large numbers of plants are constantly being screened for their possible pharmacologic value (examples which include anti-inflammatory, antimicrobial, antidiabetic, and hypotensive properties (Trease and Evans 2002) [2]. Plants have been employed in the treatment of various disease.They contain natural secondary metabolites blended in such a manner the body absorbs them with less side effects (Holistic action of herbal medicine).. The use of single isolate of plant compounds including synthetic drugs is not without its limitations.

The bio-active ingredients that have therapeutic activities in plants have holistic nature of treatment. Substances found in the medicinal plant containing the healing property of the plant are known as the active principles. They defer from plant to plant (Adebanjo et al., 1983) [3] Orthodox medicine in the process of its cure, can leave the patient with grievous side effects or even may lead to death of the patient. The use of traditional medicine can be traced down to the ancient Chinese, Indians, Africans, Egyptians, The great Britain and other countries.

In this research, a plants with a long antiquity of use in ethno-medicine which is one of the tropical forest plant with so many potentials Morinda lucida is being screened for antiemetic activity.

\subsection{Morinda lucida}

Morinda lucida belong to kingdom Plantae. The wood is yellow, brown and sometimes grey in colour. It is aso a nutrient factory and is readily available in the southwestern Nigeria. Morinda lucida like other medicinal plants is of high importance in pharmacognostic analysis, prevention, and treatment of diseases. It is a tropical rainforest tree(Adejuwon Adewale Adeneye, 2013) [4]. It is also a nutrient factory and is readily available throughout the year in southwestern Nigeria. Used in making fence and sparingly grown in southeastern states.

The leaves of Morinda lucida contain high level of vitamin $\mathrm{K}$ which helps in building of strong bone and as an anticoagulant. It is reported to possess strong trypanocidal and aortic vasorelaxant activities. The leaf and stem bark is reported to possess anticancer, hepatoprotective, cytotoxic, and genotoxic, anti-spermatogenic, hypoglycemic and antidiabetic activities.

The leaves effectively treat and improve all forms of infertility in women. Brimstone tree is locally used in the treatment of irregular menstruation, insomnia and jaundice, also in the treatment of wound infections, abscesses and chancre. The decoction is also reported to have anti-diarrhea effect.

\subsection{Morphology}

Morinda lucida is a medium sized tree can measure up to $18 \mathrm{~m}$ in height when mature (Adeneye et at., 2013) [4].

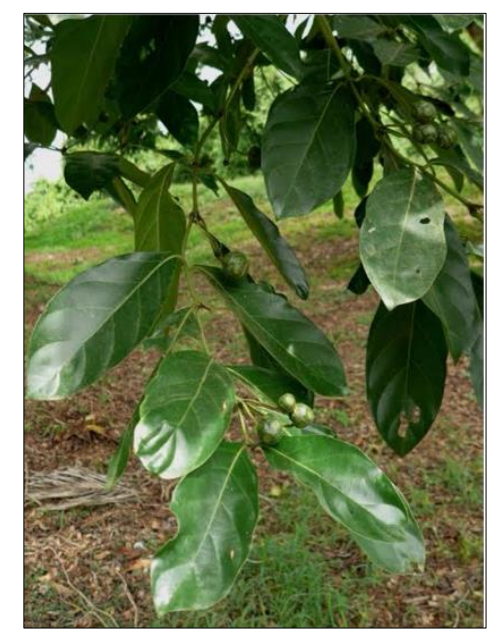

Figure 1 leaves and fruits of Morinda lucida 
The branches are often crooked or gnarled and very tough to break. Thebark is smooth scaly, grey to brown in color, not usually so big. The Leaves are opposite, simple and entire, stipules can be ovate ortriangular and can be $1-7 \mathrm{~mm}$ long and usually fall early; the petiole is up to $15 \mathrm{~cm}$ long; blade elliptical, $6-18 \mathrm{~cm} \times 2-9 \mathrm{~cm}$, base rounded,apex acute to accumulate, shiny above, sometimes finely pubescence when young, later only tufts of hairs in vein axils beneath and some hairs on the midrib. Inflorescence a stalked head $4-7 \mathrm{~mm}$ in diameter, 1-3 at the node opposite a single leaf, peduncle up to $8 \mathrm{~cm}$ long bearing at base a stalked cup-shaped gland.

\subsection{Pharmacognostic Profile}

Nomenclature and taxanomy of Morinda lucida

- Kingdom: Plantae

- clade: Angiosperms

- $\quad$ Class: Eudicots

- Subclass: Asterids

- Order: Gentianales

- Family: Rubiaceae

- Subfamily: Rubioideae

- Genus: Morinda

- $\quad$ Specie: lucida

\subsection{Other names for Morinda lucida}

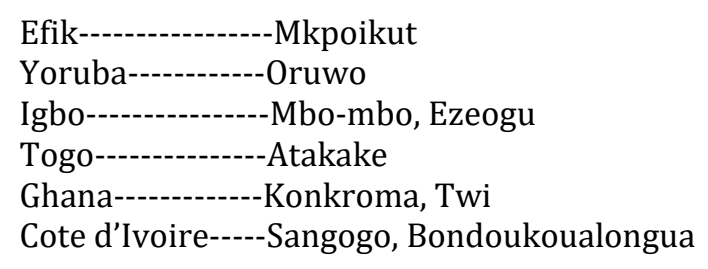

\subsection{Geographical Distribution}

Morinda lucida occurs from Senegal to Sudan and southward to Angola and Zambia. It is sometimes planted around villages, e.g. in Benin (Adeyemiet al., 2014) [5]

\subsection{Chemical constituent}

Phytochemical evaluation of the wood and bark of Morinda lucida shows about 18 anthraquinones, including the red colorants 1-methylether-alizarin, rubiadin and derivatives, lucidin, soranjidiol, damnacanthal, nordamnacanthal, morindin, munjistin and purpuroxanthin. Two anthraquinols, oruwal and oruwalol, have also been found; these give a yellow colour and possibly are intermediates in the formation of anthraquinones. In addition to anthraquinones, tannins, flavonoids and saponosides have been isolated (Cardon. D. 2003) [6].

\section{Previous works on Morinda lucida}

\subsection{Antisickling properties of Morinda lucida}

Anthocyanins extracts from a Congolese plant Morinda lucida were evaluated for their antisickling activity using microscopic technique. The red blood cells (RBCs) were observed to change from the sickled shape to normal biconcave cells in the presence of 2 per cent sodium metabisulfite. The treated SS RBCs demonstrated a remarkable similarity to normal blood values (Radius $=3.3 \pm 0.3 \mathrm{~mm}$ ).

The minimal concentration of normalization (MCN) of sickle cell erythrocytes was $0.195 \mu \mathrm{g} / \mathrm{mL}$.

The antisickling activity was found to be dose dependent. Anthocyanins extracts was found to be responsible of the inhibition of the sickling process, thus, justifying the claims of the traditional medical practitioners and suggesting a possible correlation between the chemical composition of this plant and its use in traditional medicine (Atibu et al., 2010) [7].Asuzu IU, and Chime CN. (1990), Effects of Morinda lucida leaf extract on trypanosoma brucei infection in mice. Journal of Ethnopharmacol.; 30:307- 313. 


\subsubsection{Effects of Morinda lucida on Plasmodium falciparum}

The effects of three compounds which includes

(1) digito-lutein, (2) rubiadin 1-methyl ether and (3) damnacanthal extracted from the stem bark and the roots of Morinda lucida Benth. on the growth of Plasmodium falciparum in vitro were investigated. The number of parasites (schizonts) decreased significantly in a dose-dependent manner, and 100\% of inhibition was obtained with 30 to $40 \mu \mathrm{g}$ of each compound tested (Koumaglo et al, 2016) [8].

\subsubsection{Antidiabetic Property}

This was performed using $\alpha$-amylase from Aspergillusoryzae and $\alpha$-glucosidase from Saccharomyces cerevisiae.Aqueous extract of Morinda lucida gave the highest percentage yield (9.99\%) of the plant out of the three extracts (compared to acetone and ethanolic extracts) and possesses the highest inhibitory activity against $\alpha$-amylase (IC 50 value of $2.30 \mathrm{mg} / \mathrm{mL}$ ) and $\alpha$-glucosidase ( $\mathrm{IC}_{50}$ value of $2.00 \mathrm{mg} / \mathrm{mL}$ ). Kinetic analysis revealed that the aqueous extract of this plant leaf inhibited the $\alpha$-amylase competitively but displayed mixed noncompetitive mode of inhibition towards $\alpha$ glucosidase (Kazeemet al., 2013).[9].

\subsubsection{Cognitive enhancing property}

Morinda lucida and Peltophorumpterocarpum showed considerable enhancement of cognition in scopolamine induced amnesic mice (ElufioyeTaiwo 0 et al, 2017).[10].

\subsubsection{Antioxidant propery}

Morinda lucida (L.) Benth. (Rubiacae) is used in traditional medicine in many West African countries for the treatment of various human diseases. The leaves and roots of this plant were subjected to hydrodistillation to obtain volatile oils which were analyzed by high resolution GC/MS. Fifty compounds were identified in the leaf volatile oil and the major compounds were $\alpha$-terpinene and $\beta$-bisabolene. In the root oil, some compounds were identified, the major constituents being 3-fluoro-p-anidine and hexadecanoic acid. Antioxidant activities of the oils were examined using the DPPH, ABTS, reducing power and lipid peroxidation assays. All assays were concentration dependent with varying antioxidant potentials. The antioxidant activity of the root volatile oil of M. lucida was similar to that of the standard drugs used ( Oludare et al., 2016)[11].

\subsection{General uses and Ethnobotanical Importance}

The wood of Morinda lucida yields yellow to red dyes. In Nigeria and Gabon the root bark is used to dye textiles into scarlet red. On occasions of national grief or the death of a chief, the Ashanti people of Ghana dye cotton cloths red with the root bark of Morinda lucida. These cloths, called 'kobene', are worn as mourning dress by official people and by the family of the deceased. The root is the most important traditional source of yellow dye for textiles in the Kasai Province of DR Congo. It can be used without a mordant. The root is also added to indigo vats in Côte d'Ivoire, to contribute both to the fermentation and reduction process necessary for dyeing with indigo and to get darker blues. In this process it is often combined with leafy twigs of Saba comorensis (Bojer) Pichon (synonym: Saba florida (Benth.) Bullock). In the region of Kasongo in north-eastern DR Congo, young leaves of Morinda lucida are combined with leaves of a Philenoptera species (a source of indigo) to obtain a pale green dye used in basket weaving.

The bitter-tasting roots are used as flavouring for food and alcoholic beverages and in Nigeria they are popular as chewing sticks. The wood is excellent for making charcoal, but is also used for construction, mining props, furniture, canoes, poles and fuelwood. The leaves are used for cleaning and scouring, e.g. of calabashes. In West Africa Morinda lucida is an important plant in traditional medicine (Sofoworaet al., 1992) [12]. Decoctions and infusions or plasters of root, bark and leaves are recognized remedies against different types of fever, including yellow fever, malaria, trypanosomiasis and feverish condition during childbirth. The plant is also employed in cases of diabetes, hypertension, cerebral congestion, dysentery, stomach-ache, ulcers, leprosy and gonorrhoea. In Nigeria Morinda lucida is one of the 4 most used traditional medicines against fever. In Côte d'Ivoire a bark or leaf decoction is applied against jaundice and in DR Congo it is combined with a dressing of powdered root bark against itch and ringworm (Cardon D., 2003) [6].

Morinda lucida is rich source of two powerful antioxidants, vitamins A and E which could be effective in combating degenerative diseases like atherosclerosis; vitamin $\mathrm{K}$, different secondary metabolites responsible for the ethnomedicinal properties of the plant,- alkaloids, tannins, saponins, flavonoids, phenols. Nutrient component which showed moderate qualities of proximate compounds- carbohydrates, protein, fat, fiber, ash and high moisture content; bioactive phytochemical which act as antibiotic, antiviral, anti- plasmodial and anti- parasitic. 


\subsection{Emesis}

Emesis is an act or process of vomiting or throwing up.

\subsubsection{Other names of vomiting}

Emesis, Puking, Barfing Heaving, throwing up, blowing chunks up, Chucking, Spewing

Vomiting:Vomiting is a complex series of action involving the stomach, oesophagus and pharynx with the voluntary muscles of the chest and abdomen and reselting in the ejection of food from the stomach. These actions are coordinated by a vomiting centre in the medulla. (John Trounce 1973) [13].

Vomiting is also the forceful expulsion of contents of the stomach and often, the proximal small intestine. It is a manifestation of a large number of conditions, many of which are not primary disorders of the gastrointestinal tract. Regardless of cause, vomiting can have serious consequences, including acid-base derangments, volume and electrolyte depletion, malnutrition and aspiration pneumonia.

\subsection{The Act of Vomiting}

Vomiting is usually experienced as the finale in a series of three events,

Nausea is an unpleasant and difficult to describe psychic experience in humans and probably animals. Physiologically, nausea is typically associated with decreased gastric motility and increased tone in the small intestine. Additionally, there is often reverse peristalsis in the proximal small intestine.

Retching ("dry heaves") refers to spasmodic respiratory movements conducted with a closed glottis. While this is occurring, the antrum of the stomach contracts and the fundus and cardia relax. Studies with cats have shown that during retching there is repeated herniation of the abdominal esophagus and cardia into the thoracic cavity due to the negative pressure engendered by inspiratory efforts with a closed glottis.

Emesis or vomiting is when gastric and often small intestinal contents are propelled up to and out of the mouth. It results from a highly coordinated series of events that could be described as follows:

- A deep breath is taken, the glottis is closed and the larynx is raised to open the upper esophageal sphincter. Also, the soft palate is elevated to close off the posterior nares.

- The diaphragm is contracted sharply downward to create negative pressure in the thorax, which facilitates opening of the esophagus and distal esophageal sphincter.

- Simultaneously with downward movement of the diaphragm, the muscles of the abdominal walls are vigorously contracted, squeezing the stomach and thus elevating intragastric pressure. With the pylorus closed and the esophagus relatively open, the route of exit is clear.

\subsubsection{Control of Vomition}

The complex, almost sterotypical set of activities that culminate in vomiting suggest that control is central, which indeed has been shown to be true. Within the brainstem are two anatomically and functionally distinct units that control vomiting:

Bilateral vomition centers in the reticular formation of the medulla integrate signals from a large number of outlying sources and their excitement is ultimately what triggers vomition. Electric stimulation of these centers induces vomiting, while destruction of the vomiting centers renders animals very resistant to emetic drugs. The vomiting centers receive afferent signals from at least four major sources:

\section{Pathophysiology}

Receptors on the floor of the fourth ventricle of the brain represent a chemoreceptor trigger zone, known as the area postrema, stimulation of which can lead to vomiting. The area postrema is a circumventricular organ and as such lies outside the blood-brain barrier; it can therefore be stimulated by blood-borne drugs that can stimulate vomiting or inhibit it (Hornby p. 2001) [14]. 


\subsubsection{Causes and Consequences of Vomiting}

Simple vomiting rarely causes problems, but on occasion, can lead to such serious consequences as aspiration pneumonia. Additionally, severe or repetitive vomiting results in disturbances in acid-base balance, dehydration and electrolyte depletion. In such cases, the goal is to rapidly establish a definitive diagnosis of the underlying disease so that specific therapy can be instituted. This is often not easy and, in many cases, it is advantageous to administer antiemetic drugs in order to suppress vomiting and reduce its squeal.

\subsection{Treatment}

An antiemetic is a drug that is effective against vomiting and nausea. Antiemetics are typically used to treat motion sickness and vomiting due to the side effects of medications such as opioids and chemotherapy.

Antiemetics act by inhibiting the receptor sites associated with emesis. Hence, anticholinergics, antihistamines, dopamine antagonists, serotonin antagonists, and cannabinoids are used as antiemetic,

\section{Aim of study}

This study was carried out:

- To carry out pharmacohnostic screening of the leaves of Morinda lucida

- Its antiemetic screening on two weeks old chickens.

\section{Significance of study}

- To establish the effect of Morinda lucida as an antiemetic drug in children and adults

\section{Justification}

- This research study on Morinda lucida leaf is important to evaluate its antiemetic effect and to encourage its use in the treatment and control of emesis.

- To produce a cheap and affordable anti-emetic drug of natural source.

\section{Material and methods}

\subsection{Materials}

Solvent: Ethanol and distilled water

Reagent: dilute and conc. HCL, Dragendoff reagent, ferric chloride solution, Mayer's reagent, Wagner's reagent, Fehling's solution (A\&B), ruthenium red, iodine solution, phloroglucinol, tetraoxosulphate (vi) acid (H2SO4), potassium hydroxide, chloroform, distilled water.

Animal used: 2weeks old chicks (weight range 158g-372g)

Standard drug: chlorpromazine

Apparatus: Analytical balance (triple beam balance OHAUS 2010), petri dishes, laboratory water bath (Genilab limited), conical flask, stopwatch (venus), crucible, hot air oven (Gallenkamp, England model OV-335), microscope (supertex). Clean glass slide, cover slip, whattman filter paper No. 1, cotton wool, indelible maker, syringes.

\subsection{Preparation Of the Plant Material}

\subsubsection{Collection Process}

The leave plant was collected from the branches of the main tree of Morinda lucida located in Orlu, Imo state, Nigeria. It was identified by the H.O.D,Pharmacognosy Madonna University, Elele Campus, Rivers State Nigeria. It was cut and well package in way to avoid contamination or accumulation of dirt.The leaves were carefully handpicked and washed off of dirt, after which, it was spread on newspapers and separated to prevent overlapping which might lead to deterioration by damp accumulation which in turn may cause bacterial contamination. It was then air dried under room temperature 
for 14 days.it was packaged and blended using a roller mill (electric blender) into a coursepowder.andstored in an airtight container for pharmacognostic tests, chromatographic analysis and anti-emetic evaluation.

\subsection{Extraction Procedure}

Approximately $520 \mathrm{~g}$ of the powdered plant material was soaked in $2500 \mathrm{ml}$ of ethanol at room temperature for $72 \mathrm{hours}$. The content was filtered with Whatman No.1 filter paper and the filtrate was gently condensed in rotary evaporator, evaporated to dryness in hot water bath. Then packed in separate clean dry bottles and kept in the refrigerator until required.

\subsection{Macroscopic Examination of the Leaves}

The fresh sample was used for the description which was done under the following headings Petiole, Lamina, Composition, Venation, Margin, Apex, Base, Taste, Odour, Size, Surface, Outline, Colour.

\subsection{Microscopic Evaluation of Leaves}

This was carried out in order to study the anatomy of the leaf. The fresh sample from the various sections of the leaf were used for the microscopic examination.

\subsection{Transverse Section of The Leaf}

Transverse section of the fresh leave was prepared with the help of sharp blade and was collected in a Petri dish. The sections were transferred into a staining jar containing safranin solution and allowed to stand for 2 minutes and then washed in another petri dish containing distilled water. The sections were mounted on clean glass slide with help of glycerin water and covered by glass slip. Then slides were observed under microscope.

\subsection{Chemo microscopy Test}

The following test for the different cell wall components of the plant using powdered plant material were carried

\subsubsection{Test for Lignin}

1-2 drops of phloroglucinol in alcohol was added to the powdered sample, allowed to dry and then 1-2 drops of concentrated hydrochloric acid were added and examined for a red colour under the microscope.

\subsubsection{Test for Cellulose}

To the powdered plant material, iodine and 80\% $\mathrm{H} 2 \mathrm{SO} 4$ solution was added and examined for a blue-black coloration.

\subsubsection{Testfor Hemicellulose}

To the powdered plant material $20 \%$ of sodium hydroxide was added and examined for a red coloration.

\subsubsection{Test for Mucilage}

To the powdered sample of Morinda lucida, ruthenium red was added and examined for a pink coloration.

\subsubsection{Test For Suberin andCutin}

Chlorine, zinc iodide and dilute tincture of alkane was added to the powdered sample of Morinda lucida and examined for a yellow colour and red stained walls.

\subsubsection{Test for Calcium Oxalate Crystals}

The powdered plant material was cleared with chloral solution and observed for calcium oxalate crystal. A few drops of concentrated $\mathrm{H} 2 \mathrm{SO} 4$ were added and viewed under the microscope and examined for the disappearance of oxalate crystals.

\subsection{Phytochemical Tests}

The powder and extract of Morinda lucida was screened for their phytochemical components. The tests were carried out according to the procedures and methods outlined by Harbourne (1973) [15] involves testing for the presence or absence of the following plant constituent: alkaloids, saponins, glycosides, resins, flavonoids, tannins, oils, carbohydrate. 


\subsection{Determination of Analytical Standard}

\subsubsection{Percentage Moisture Content}

A crucible plate was oven dried at the temperature of $40^{\circ} \mathrm{C}$ for about 15 minutes, cooled in a desicator and weighed (W1), $2 \mathrm{~g}$ of the powder drug of morinda lucida (W2) was weighed into the crucible plate and gently heated in the oven to a tepmperature of about $105^{\circ} \mathrm{C}$ for 6 hours at intervals of 3,2,1 houruntil a constant weight (W3) is obtained and cooling was done in a desicator before rere weighing.

$$
\% \text { moisture }=\frac{W 2-W 3 \times 100}{W 2-W 1}
$$

\subsection{Determination of Extractive value}

\subsubsection{Total Ash Value}

A porcelain crucible was placed in muffle furnace for about 15 minutes at 30C, cooled in a desicator for about one hour and the crucible was weighed (W10.3g of the sample is accurately weighed into the preheated porcelain crucible and reweighed (W2). The sample is ashed in muffle furnace at 650C for about 6 hours until the sample turns grey (white ash). The crucible is removed with tong, cooled in a desicator and reweighed (W3). The percentage ash content is determined by the relationship;

$$
\% \text { Ash }=\frac{W 2-W 3 \times 100}{W 2-W 1}
$$

\subsection{Chromatogenic Analysis}

\subsubsection{Choosing A Solvent System}

To ensure a good separation and identification of chemical constituent using chromatography, it is important that a good solvent system is chosen. the solvent system used should be one that carry along the spots as it moves upwards and it should not move to the solvent front. Ethanol and chloroform was used in a ratio of 1:4 i.e 10mls of ethanol and $40 \mathrm{mls}$ of chloroform.

Thin Layer Chromatograhy

\subsubsection{Test samples}

Ethanol extract of Morinda lucida

Standard drug (Chlorpromazine)

Solvent system: chloroform:Ethanol

\subsection{Materials}

Percolated chromatographic plates, chromatographic tanks

Thin layer plate of 20/10 coated with silica gel was used. The plate was first activated by heating in the laboratory oven at a temperature of 110-degree celcius for five (5) minutes. The origin was marked at $2 \mathrm{~cm}$ from the base of the plate while the solvent front was $10 \mathrm{~cm}$ from the origin. All the extracts and the standard drug were spotted at the baseline using a capillary tube. The plate was then inserted into the chromatography tank and allowed to develop until it got the solvent front. The plate was removed and the solvent front marked and the plate was allowed to dry and viewed under the UV light. The spots produced were marked. Then the distance moved by different spots were measured using a ruler and the values gotten were used to determine the Rf value. The Rf was calculated using the formula;

$$
\mathrm{Rf}=\frac{\text { distance traveled } \text { by the spot }}{\text { distance traveled by the solvent }}
$$




\subsection{Acute Toxicity Study (LD50)}

The acute toxicity of Morinda lucida was evaluated using a total of 21 chickens of both sexes, it was carried out using the method described by Dietrich Lorke, 1983.[16]. The test was carried out in three stages. Stage 1 contained 9 chickens divided into three groups of 3 chickens per group. Group one received $100 \mathrm{mg} / \mathrm{kg}$ oral administration of the extract, Group 2 received $1000 \mathrm{mg} / \mathrm{kg}$ of the extract, while Group 3 received $1500 \mathrm{mg} / \mathrm{kg}$. The animals were monitored constantly for 24 hours for mortality. The results from the first stage were noted, then the second stage was carried out.

The second stage involved four (4) chickens. They were grouped into two (2) groups of 2 animals in each group. The first group received $2000 \mathrm{mg} / \mathrm{kg}$ of the extract orally while $2500 \mathrm{mg} / \mathrm{kg}$ of the extract was given the the second group. The animals were once again monitored for another 25 hours and the number of deaths was noted. Then the third stage was carried out.

The third stage involved six (6) chickens. They were grouped into three (3) groups with two animals in each group. The first group received $3000 \mathrm{mg} / \mathrm{kg}$ of the extract orally, group 2 received $3500 \mathrm{mg} / \mathrm{kg}$ of the extract, and lastly $5000 \mathrm{mg} / \mathrm{kg}$ of the extract was given to the third group. The animals were monitored for 24 hours for mortality.

\subsection{Anti-Emetic Screening}

The anti-emetic activity of the ethanol extract of Morinda lucida was evaluated using the method explained by Akita et al, (1998) [17]. A total of 10 chickens were used. The animals were obtained from the animal house Imo state university. They were grouped into five groups of 2 animals per group. The animals were treated as follows;

Group 1 with average weight of $0.223 \mathrm{~kg}$ received $10 \mathrm{ml} / \mathrm{kg} 0.9 \%$ normal saline orally; Group 2 with average weight of $0.234 \mathrm{~kg}$ received $50 \mathrm{mg} / \mathrm{kg}$ of chlorpromazine orally; Group 3 with average weight of $0.267 \mathrm{~kg}$ received $250 \mathrm{mg} / \mathrm{kg}$ of extract orally; Group 4 with average weight of $0.284 \mathrm{~kg}$ received $500 \mathrm{mg} / \mathrm{kg}$ of extract orally; Group 5 with average weight of $0.275 \mathrm{~kg}$ received $750 \mathrm{mg} / \mathrm{kg}$ of extract orally.

\section{Results}

Table 1 Results forthe Macroscopic Description of Morinda lucida

\begin{tabular}{|c|c|}
\hline Character & Description \\
\hline Colour & Green \\
\hline Condition & Fresh \\
\hline Venation & Reticulate \\
\hline Base & Assymetric \\
\hline Margin & Sinulate \\
\hline Petiole & Petiole \\
\hline pex & Acuminate \\
\hline Surface & labrous/pubescent \\
\hline Outline & Smooth \\
\hline Texture & Thick and fleshy \\
\hline Odour & Aromatic/pungent \\
\hline Taste & Aromatic/ bitter \\
\hline Leaf type & Simple \\
\hline
\end{tabular}


Table 2 Chemomicroscopic Data for Morinda lucida

\begin{tabular}{|c|c|c|}
\hline Test & Observation & Inference \\
\hline $\begin{array}{l}\text { Lignin } \\
\text { Powder }+ \text { phloroglucinol }+ \\
\text { concentrated hydrochloric acid. } \\
\text { observed under microscope }\end{array}$ & $\begin{array}{l}\text { Fibres were pink in } \\
\text { colour }\end{array}$ & Lignin \\
\hline $\begin{array}{l}\text { Starch } \\
\text { Powder + N/50 iodine, then } \\
\text { observed under the microscope }\end{array}$ & $\begin{array}{l}\text { Blue } \quad \text { black } \\
\text { colouration }\end{array}$ & Starch present \\
\hline $\begin{array}{l}\text { Mucilage } \\
\text { Powder + Ruthenium }\end{array}$ & $\begin{array}{l}\text { Absence of pink } \\
\text { coloration }\end{array}$ & $\begin{array}{l}\text { Mucilage } \\
\text { absent }\end{array}$ \\
\hline $\begin{array}{l}\text { Calcium oxalate } \\
\text { Powder }+\quad \text { concentrated } \\
\text { Hydrochloric acid }\end{array}$ & $\begin{array}{l}\text { Disappearance of } \\
\text { calcium oxalate }\end{array}$ & $\begin{array}{l}\text { Calcium } \\
\text { oxalate present }\end{array}$ \\
\hline $\begin{array}{l}\text { Cellulose } \\
\text { Powders }+ \text { iodine }+80 \% \text { sulphuric } \\
\text { acid }\end{array}$ & $\begin{array}{l}\text { Blue-black } \\
\text { colouration }\end{array}$ & $\begin{array}{l}\text { Cellulose } \\
\text { present }\end{array}$ \\
\hline $\begin{array}{l}\text { cutin and suberin } \\
\text { Powder }+ \text { Chlorine-zinc-iodine }+ \\
\text { dilute tincture of alkane }\end{array}$ & $\begin{array}{l}\text { Absence of light } \\
\text { yellow colour and red } \\
\text { stained walls }\end{array}$ & Cutin absent \\
\hline $\begin{array}{l}\text { Hemicellulose } \\
\text { Powder }+20 \% \text { Sodium Hydrogen }\end{array}$ & $\begin{array}{l}\text { Presence of red } \\
\text { colouration }\end{array}$ & $\begin{array}{l}\text { Hemicellulose } \\
\text { present }\end{array}$ \\
\hline
\end{tabular}

The various chemical test carried out indicated the presence (significantly, moderately or mild) and absence of the following chemical groups.

Results of the phytochemical test carried out on the Aqueous and Eethanolic extract of Morind lucida

Table 3 Results of Phytochemical Test

\begin{tabular}{|l|l|c|}
\hline \multicolumn{1}{|c|}{ Test } & \multicolumn{1}{c|}{ Observation } & Inference \\
\hline Test for alkaloids & Milky precipitate was observed. & Alkaloids present \\
\hline Mayer's Reagent & Brick red coloration observed & Alkaloids present \\
\hline Dragendorff's Reagent & Reddish brown precipitate observed & Alkaloids present \\
\hline Wagner's Reagent & Yellow precipitate obseverd & Alkaloids present \\
\hline Picric acid & \multicolumn{2}{|c|}{} \\
\hline Test for flavonoids & $\begin{array}{l}\text { Yellow colouration confirmed the } \\
\text { precence of flavonoids }\end{array}$ & Flavonoids present \\
\hline Ammonium test & $\begin{array}{l}\text { Brick red precipitate confirms the } \\
\text { presence of reducing sugar. }\end{array}$ & Glycosides present \\
\hline Test for glycosides & \multicolumn{2}{|l}{} \\
\hline Fehling's test &
\end{tabular}




\begin{tabular}{|l|l|c|}
\hline Frothing test & $\begin{array}{l}\text { A stable froth (foam) upon standing } \\
\text { indicates the presence of saponin }\end{array}$ & Saponinss present \\
\hline Emulsion test & $\begin{array}{l}\text { Formation of an emulsion indicates the } \\
\text { presence of saponin }\end{array}$ & saponins present \\
\hline Test for tannins & $\begin{array}{l}\text { Greenish black coloration indicates } \\
\text { presence of tannins }\end{array}$ & Tannins present \\
\hline Ferric chloride test & $\begin{array}{l}\text { Reddish color indicates } \\
\text { the presence of tannin }\end{array}$ & Tannins present \\
\hline Lead acetate test
\end{tabular}

Table 4 Results of the Analytical Standards

\begin{tabular}{|l|c|}
\hline \multicolumn{1}{|c|}{ Parameter } & \%(w/w) \\
\hline Moisture content & $7 . .5 \%$ \\
\hline Total ash value & 1.82 \\
\hline \multicolumn{2}{|c|}{ Percentage yield }
\end{tabular}

Results of the Acute Toxicity Test of ethanolic extract of Morinda lucida

Table 5 Results of acute toxicity test

\begin{tabular}{|c|c|c|}
\hline Stages & Dose & Number of death \\
\hline \multirow{3}{*}{ Stage 1 } & $100 \mathrm{mg} / \mathrm{kg}$ & $0 / 3$ \\
\cline { 2 - 3 } & $1000 \mathrm{mg} / \mathrm{kg}$ & $0 / 3$ \\
\cline { 2 - 3 } & $1500 \mathrm{mg} / \mathrm{kg}$ & $0 / 3$ \\
\hline \multirow{2}{*}{ Stage2 } & $2000 \mathrm{mg} / \mathrm{kg}$ & $0 / 2$ \\
\cline { 2 - 3 } & $2500 \mathrm{mg} / \mathrm{kg}$ & $0 / 2$ \\
\hline \multirow{2}{*}{ Stage3 } & $3000 \mathrm{mg} / \mathrm{kg}$ & $0 / 2$ \\
\cline { 2 - 3 } & $3500 \mathrm{mg} / \mathrm{kg}$ & $0 / 2$ \\
\cline { 2 - 3 } & $5000 \mathrm{mg} / \mathrm{kg}$ & $0 / 2$ \\
\hline
\end{tabular}

Table 6 Results of Antiemetic Analysis

\begin{tabular}{|c|c|c|c|c|c|c|c|}
\hline Groups & $\begin{array}{l}\text { Dose and } \\
\text { treatment }\end{array}$ & $\begin{array}{l}\text { No.of } \\
\text { Retches.10Min. }\end{array}$ & $\begin{array}{l}\text { No } \\
\text { ofRetches } \\
\text { (20Min) }\end{array}$ & $\begin{array}{l}\text { No. of } \\
\text { Reches } \\
\text { (30Min) }\end{array}$ & $\begin{array}{l}\text { No. of } \\
\text { Reches } \\
\text { (40Min) }\end{array}$ & $\begin{array}{l}\text { No. of } \\
\text { Reches } \\
\text { (60Min) }\end{array}$ & $\begin{array}{l}\text { No. of } \\
\text { Reches } \\
\text { (70Min) }\end{array}$ \\
\hline \multirow[t]{2}{*}{ Group 1} & \multirow{2}{*}{$\begin{array}{l}10 \mathrm{ml} / \mathrm{kg} \\
\text { Normal saline }\end{array}$} & $\mathrm{A}: 47$ & 43 & 40 & 39 & 35 & 32 \\
\hline & & B: 48 & 46 & 42 & 39 & 37 & 36 \\
\hline \multirow[t]{2}{*}{ Group 2} & \multirow{2}{*}{$\begin{array}{l}50 \mathrm{mg} / \mathrm{kg} \\
\text { Chlorpromazine }\end{array}$} & $A: 10$ & 4 & 1 & 0 & 0 & 0 \\
\hline & & $\mathrm{B}: 10$ & 3 & 0 & 0 & 0 & 0 \\
\hline \multirow[t]{2}{*}{ Group 3} & \multirow{2}{*}{$\begin{array}{l}250 \mathrm{mg} / \mathrm{kg} \\
\text { Extract }\end{array}$} & A: 12 & 5 & 2 & 0 & 0 & 0 \\
\hline & & B: 10 & 4 & 2 & 0 & 0 & 0 \\
\hline \multirow[t]{2}{*}{ Group 4} & \multirow{2}{*}{$\begin{array}{l}500 \mathrm{mg} / \mathrm{kg} \\
\text { Extract }\end{array}$} & A: 6 & 2 & 0 & 0 & 0 & 0 \\
\hline & & B: 6 & 1 & 0 & 0 & 0 & 0 \\
\hline \multirow[t]{2}{*}{ Group 5} & \multirow{2}{*}{$\begin{array}{l}750 \mathrm{mg} / \mathrm{kg} \\
\text { Extract }\end{array}$} & A: 6 & 1 & 0 & 0 & 0 & 0 \\
\hline & & B: 5 & 1 & 0 & 0 & 0 & 0 \\
\hline
\end{tabular}


Table 7 Results Showing Mean Number of Retches and Percentage Inhibition

\begin{tabular}{|l|c|c|}
\hline Groups and treatment & Mean No. of Raches & Percentage Inhibition \\
\hline $\begin{array}{l}\text { Group 1 } \\
10 \mathrm{mlmg} / \mathrm{kg} \text { Normal saline }\end{array}$ & 48.4 & ------- \\
\hline $\begin{array}{l}\text { Group 2 } \\
50 \mathrm{mg} / \mathrm{kg} \text { Chlorpromazine }\end{array}$ & 1.5 & $97 \%$ \\
\hline $\begin{array}{l}\text { Group 3 } \\
250 \mathrm{mg} / \mathrm{kg} \text { Extract }\end{array}$ & 3.0 & $94 \%$ \\
\hline $\begin{array}{l}\text { Group 4 } \\
500 \mathrm{mg} / \mathrm{kg} \text { Extract }\end{array}$ & 1.76 & $96 \%$ \\
\hline $\begin{array}{l}\text { Group 5 } \\
750 \mathrm{mg} / \mathrm{kg} \text { Extract }\end{array}$ & 1.75 & $96 \%$ \\
\hline
\end{tabular}

The percentage inhibition was calculated by the following formulae:

$$
\text { Inhibition }(\%)=(A-B / A) \times 100
$$

Where $\mathrm{A}=$ Frequency of retching in control group

$\mathrm{B}=$ Frequency of retching in test group

\section{Discussion}

The morphological description of the leaves from the collected sample was found to be identical with that described by Evans 2002 [2].

The leaves have the following: cell wall component: lignin, cellulose, hemicellulose, starch, calcium oxalate and mucilage, cutin and suberin were absent.

Preliminary phytochemical screening of the plant Morinda lucida, revealed the presence of several biological substances such as alkaloids, tannins, saponins and so on, this is supported by the findings by Adeneye A.A 2013.[4].The presence of these secondary metabolites in this plant act as a remedy for diabetic, antioxidative, wound healing, effective in combating degenerative illnesses like atherosclerosis, and so on. The nonsugar parts of saponins also have direct antioxidant activity and studies on antioxidants has shown its ability to attenuate nausea and vomiting

Ash constitutes the inorganic residues obtained after complete combustion of crude drugs; thus, ash value is a validity parameter used to assess the purity of a given drug (Kokate et al., 2008) [18].

Extractive values are representative of the presence of the polar or non-polar extractive compounds in the plant material.

Acute toxicity test was carried out on the chicks and there was no recorded death in the animals.

Antiemetic activities of the ethanol extract of Morinda lucida were reported, the plant (leaf) extract attenuated the number of retches at a very close range with chlorpromazine which is the standard drug. It exhibited an extremely significant effect in the control of emesis. The antiemetic extract was able to stop the retching within 30 minutes and in higher concentrations the emesis stopped under 30 minutes. The antiemetic effect of Morinda lucida is not dose dependent. 


\section{Conclusion}

This research work presented demonstrated that the ethanolic extracts of leaf of $M$. lucida have antiemetic activity. The extracts inhibited emesis at almost the same level with the standard drug chlorpromazine. It is very nutritious due to its chemical composition. It also investigated the phytochemical constituents of the ethanolic extract. The current findings are a step forward to increasing knowledge and usefulness of M. lucida as a medicinal plant. The leaves are considered safe. The results of this study could be of great importance therefore it is recommended that more tests on antiemetic activity of this plant be carried.

\section{Recommendation}

It is thereby recommended that the medicinal plant $M$. lucida should be studied and exploited for future use as an antiemetic drug.

\section{Compliance with ethical standards:}

\section{Acknowledgments}

I acknowledge Laboratory Technologist in Pharmacognosy Department, faculty of pharmacy, Madonna University Nigeria, Mr. B Uwakwe who cared for the experimental animals.

I also acknowledge late Mrs Mary Osuala, my mother who introduced the use of Morinda licida in our family as antivomiting crud drug.

\section{Disclosure of conflict of interest}

There is no conflict of interest among the authors.

\section{Statement of ethical approval}

The protocol of this study was approved by the Faculty of Pharmacy Ethical committee Madonna University Nigeria.

\section{References}

[1] Sofowora A. Medicinal plants and Traditional medicine in African 2ndEdn. Spectrum Books limited, Ibadan, Nigeria. 1993; 53

[2] Evans WC, Trease GE, Evans D. Trease and Evans Pharmacognosy, 15th edition. Edinburgh,Saunders. 2002; 249: 454.

[3] Adebanjo AO, Adewunmi CO, Essien EE. Anti infective agents of higher plants. 5th International Symposium in Medical Plants, university of Ile ife(OAU), Nigeria. 1983; 152-158.

[4] Adeneye AA. Profile of Morinda lucida leaf fractions on blood glucose and lipids in normal and alloxan-induced hyperglycemic rats.Pharmacologia. 2013; 4(5): 408-413.

[5] Adeyemi TOA, Ogboru RO, Idowu RO, Owoeye EA, Isese MO. Phytochemical screening and health potentials of M. lucida Benth. International Journal of Innovation and Scientific Research. 2014; (2): 515-519.

[6] Cardon D. Le monde des teinturesnaturelles.Belin, Paris, France. 2003; 586.

[7] Asuzu IU, Chime CN. Effects of Morinda lucida leaf extract on trypanosoma brucei infection in mice. Journal of Ethnopharmacol. 1990; 30: 307- 313.

[8] Koumaglo K, Gbeassor M, Nikabu O, De Souza C, Werner W. Effects of three compounds extracted from M. lucida on Plasmodium falciparum. Planta Med. 2016; 58(6): 533-544.

[9] Kazeem MI, Adamson JO, Ogunwande IA. Modes of inhibition of Alpha amylase and Alpha glucosidase by aqueous extract of the leaves of Morinda lucida Benth leaf. Biomed Res Int Article ID 527570. 2013.

[10] TO Elufioye, SC Machie. Anticholinesterase activities of methanol extract and partitioned fractions of Acanthospermumhispidum DC Nigerian Journal of Natural Products and Medicine.2017. 
[11] Olufemi Oludare Aluko,Ayobami Emmanuel Adebayo, Titilayo Florence Adebisi,Mathew Kolawole Ewegbemi, Abiodun Tolani Abidoye, and Bukola Faith Popoola : 06 February 2016 Knowledge, attitudes and perceptions of occupational hazards and safety practices in Nigerian healthcare workers: BMC Biologia Futura.

[12] Sofowora A. Medicinal plants and Traditional medicine in Africa John Viley and sons ltd. Chichester, England. $1982 ; 142-145$.

[13] John Trounce. Clinical pharmacology for Nurses 6th edition. 1983; 105.

[14] Hornby PJ. Central neurocircuiting associated with emesis. The American journal of medicine. 2001.

[15] Harborne JB. Phytochemical methods, Chapman and Hall Ltd., London. 1978; 49-188.

[16] Lorke D. A new approach to practical acute toxicity testing.Arch. Toxicol. 1983; 53: 275-375.

[17] Akita Y, Yang Y, Kawai T, Kinoshita K, Koyama K, Takahashi K. New assay method for surveying anti-emetic compounds from natural sources. Nat. Prod. Sci. 1998; 4(2): 72-7.

[18] Kokate CK, Purohoot AP, Gokhale SB.Analytical Pharmacognosy 42nd edition.Nivaliprakashan. 2008; 19-20. 